\title{
Gambaran Gangguan Tidur pada Pasien Pasca Stroke Iskemik
}

\author{
Alya Ramadhini ${ }^{1}$, Yuliarni Syafrita ${ }^{2}$, Russilawati ${ }^{3}$ \\ ${ }^{1}$ Profesi Dokter Fakultas Kedokteran Universitas Andalas \\ ${ }^{2}$ Bagian Neurologi FK UNAND/ RSUP DR. M Djamil Padang \\ ${ }^{3}$ Bagian Pulmunologi dan Kedokteran Respirasi FK UNAND/ RSUP DR. M Djamil Padang
}

\begin{abstract}
A B S T R A C T
Latar belakang: Gangguan tidur merupakan salah satu komplikasi yang sering terjadi pada pasien stroke, serta menjadi faktor risiko pada stroke. Gangguan tidur pada pasien stroke sendiri dapat menurunkan kualitas hidup pasien pasca stroke.

Objektif: Tujuan dari penelitian ini adalah untuk mengetahui prevalensi gangguan tidur yang terjadi pada pasien pasca stroke iskemik, dan hubungannya dengan faktor risiko stroke. Metode: Penelitian cross sectional dilakukan pada pasien pasca stroke iskemik di Poliklinik Saraf Rumah Sakit Islam Ibnu Sina Padang. Informasi mengenai faktor risiko stroke diperoleh melalui data pasien dan kuesioner terpimpin. Jenis gangguan tidur dinilai melalui kuesioner Specialised Centres of Research Sleep Questionnaire tahun 2005.

Hasil: Sebanyak 57 pasien pasca stroke iskemik berpartisipasi pada penelitian ini, dengan 37 pasien pasca stroke iskemik

Types of sleep disorders were assessed through the 2005 Specialized Center of Research Sleep Questionnaire.

Results: We found out there were 57 post-ischemic stroke patients, in which 37 post-ischemic stroke patients (64.9\%) had sleep disorder incidences, such as apnea, restless legs syndrome, insomnia, and narcolepsy $(38.6 \%, 36.8 \%, 35.1 \%$, and $15.8 \%$; respectively). There was an association between age and insomnia ( $p=0.034, \mathrm{Cl}=95 \%)$. On the other hand, there was no association between other risk factors (gender, diabetes mellitus, dyslipidemia, heart disease, obesity, smoking, and alcohol consumption) and insomnia, apnea, narcolepsy, and restless legs syndrome.

Conclusions : The conclusion of this study was more than half post-ischemic stroke patients have sleep disorder with the most common were apnea. There was an association between age and insomnia.
\end{abstract} $(64,9 \%)$ memiliki kejadian gangguan tidur dengan rincian jenis gangguan tidur yang terjadi adalah apneu, restless legs syndrome, insomnia, dan narkolepsi $(38.6 \%, 36.8 \%, 35.1 \%$, dan $15.8 \%$; berurutan). Terdapat hubungan antara usia dengan kejadian insomnia $(p=0,034, \mathrm{Cl}=95 \%)$, namun tidak terdapat hubungan antara faktor risiko lainnya (jenis kelamin, diabetes melitus, dislipidemia, penyakit jantung, obesitas, merokok, dan konsumsi alkohol) dengan kejadian insomnia, apneu, narkolepsi, dan restless legs syndrome.

Simpulan: Kesimpulan penelitian ini adalah lebih dari setengah pasien pasca stroke iskemik memiliki gangguan tidur dengan kasus yang paling banyak terjadi adalah apneu. Terdapat hubungan antara usia dengan insomnia.

Kata Kunci: apneu, gangguan tidur, stroke iskemik

Background : Sleep disorder is common to be the complication in stroke patients and can be a risk factor for stroke. Sleep disorder in stroke patients decrease the quality of life.

Objective : The purpose of this study was to find out the prevalence of sleep disorders in a post-ischemic stroke patient and the association between sleep disorders and stroke risk factors.

Methods: A cross-sectional study was conducted on postischemic stroke at the neurology outpatient clinic of Ibnu Sina Islamic Hospital Padang. Information about stroke risk factors is obtained through patient data and guided questionnaires.
Keywords: apnea, sleep disorder, ischemic stroke

Apa yang sudah diketahui tentang topik ini?

Gangguan tidur merupakan salah satu komplikasi dari stroke, juga menjadi faktor risiko terjadimya stroke.

\section{Apa yang ditambahkan pada studi ini?}

Gangguan tidur yang paling banyak terjadi pada pasien pasca stroke adalah apneu (38,6\%), restless legs syndrome $(36,8 \%)$, insomnia $(35,1 \%)$, dan narkolepsi $(15,8 \%)$.

\section{CORRESPONDING AUTHOR}

Phone: 081371127379

E-mail: alyaaramadhinii@yahoo.com

\section{ARTICLE INFORMATION}

Received: July $27^{\text {th }}, 2020$

Revised: March 17th 2021

Available online: May $27^{\text {th }}, 2021$ 


\section{Pendahuluan}

Stroke menjadi penyebab kematian kedua di dunia menurut Global Burden of Disease (GBD) 2017, yaitu 80,5 kematian per 100.000 populasi setelah penyakit jantung iskemik pada tahun 2017, dengan 45\% kematian merupakan stroke iskemik. Stroke juga menjadi penyebab disabilitas kedua secara global, dengan angka kejadian disabilitas, atau disebut DALYs (disability-adjusted life-years) sebesar 132,1 juta, dengan 42\% dari angka tersebut terjadi pada stroke iskemik. ${ }^{1}$

Angka kejadian stroke di Indonesia juga menjadi perhatian khusus karena lebih tinggi dibandingkan dengan penyakit lain. Menurut GBD 2016, Indonesia menduduki posisi kedua di Asia Tenggara untuk prevalensi kejadian stroke, angka kematian, dan angka DAYLs. ${ }^{2}$ Jika dilihat pada Riset Kesehatan Dasar (RISKESDAS) 2018, prevalensi kejadian stroke di Indonesia adalah $10,9 \%$, meningkat dari $7 \%$ pada tahun $2013 .{ }^{3}$ Berdasarkan RISKESDAS 2013, jumlah penderita stroke di Sumatera Barat yang berusia lebih dari lima belas tahun diperkirakan berjumlah 1.236 .825 orang $(7,0 \%$ ) berdasarkan diagnosis tenaga kesehatan, dan diperkirakan sebanyak 2.137.941 orang $(12,1 \% 0)$ mengidap stroke berdasarkan diagnosis/ gejala. ${ }^{4}$

Stroke memiliki beberapa faktor risiko yang tidak dapat dimodifikasi dan dapat dimodifikasi. Faktor risiko yang tidak dapat dimodifikasi meliputi usia, jenis kelamin, riwayat keluarga, dan ras. Sedangkan faktor risiko yang dapat dimodifikasi seperti hipertensi, diabetes melitus, penyakit jantung, dislipidemia, obesitas, diet yang menyebabkan berbagai penyakit yang berhubungan dengan stroke, kebiasaan sendetari, merokok, dan konsumsi alkohol. Beberapa faktor risiko diatas dapat meningkatkan risiko kematian akibat stroke serta terjadinya disabilitas pasca stroke, terutama stroke iskemik. ${ }^{5}$

Stroke dapat menyebabkan terjadinya penurunan kualitas hidup penderitanya. Hal ini berkaitan dengan penurunan memori, demensia, gangguan gaya berjalan, dan penurunan fungsional lainnya. ${ }^{6}$ Selain itu, gangguan tidur sering mengikuti pasien stroke yang juga dapat menurunkan kualitas hidupnya. ${ }^{7}$ Gangguan tidur merupakan gangguan neuropsikiatri yang terjadi karena adanya defisit neurologis di daerah otak, bisa disebabkan oleh lesi yang timbul pasca stroke. Gangguan tidur pada pasien stroke iskemik dapat lebih sering terjadi setelah serangan stroke, terutama setelah 7 hari pasca serangan yang mana terjadi pengurangan volume infark di bagian otak serta terjadi penurunan neurologis termasuk penurunan kesadaran dan kekuatan motorik pada hari berikutnya. 8,9 Gangguan tidur yang sering terjadi pada pasien stroke adalah insomnia, apnea tidur, excessive daytime sleepiness (EDS) termasuk narkolepsi, serta restless legs syndrome (RLS). ${ }^{7}$ Estimasi prevalensi insomnia pada pasien pasca stroke adalah 38,6\%10, apnea tidur sebesar $72 \%,{ }^{11}$ excessive daytime sleepiness sebesar $40 \%, 12$ dan restless legs syndrome sebesar $12,4 \%{ }^{13}$

Beberapa penelitian menghubungkan kejadian stroke dengan beberapa gangguan tidur yang sering terjadi pada pasien pasca stroke. Penelitian yang dilakukan oleh Siccoli dkk menunjukkan bahwa central periodic breathing lebih sering terlihat pada pasien yang baru mengalami stroke iskemik akut beberapa hari, hal ini terkait dengan gangguan regulasi tidur karena adanya kerusakan pada bagian sistem saraf pusat yang meregulasi tidur. ${ }^{14}$ Selain itu, kejadian obstructive sleep apnea (OSA) pada pasien pasca stroke dapat menimbulkan kejadian stroke yang berulang di kemudian hari. Penelitian yang dilakukan oleh Leppävuori. dkk menunjukkan stroke juga memiliki hubungan dengan insomnia, yang mana insomnia berkaitan dengan efek fisik dan psikologis yang terjadi pada pasien pasca stroke. $^{10}$ Penelitian lain yang dilakukan oleh Elwood dkk. dengan menganalisis gangguan tidur pada pasien pasca stroke, menunjukkan munculnya gerakan tungkai periodik dalam tidur, RLS, burksism, dan mendengkur ${ }^{7}$. Gangguan tidur dapat menjadi faktor risiko terjadinya stroke, namun gangguan tidur juga dapat memperburuk penyakit stroke yang diderita. ${ }^{15}$

Gangguan tidur sendiri masih belum menjadi perhatian bagi pasien stroke sehingga luput dari penegakan diagnosis dan tatalaksana dari gangguan tidur tersebut. Luputnya diagnosis gangguan tidur pada pasien stroke ini dapat menyebabkan meningkatnya insiden stroke dan munculnya kembali stroke tersebut di kemudian hari. ${ }^{16}$

Berdasarkan pemaparan di atas bahwa gangguan tidur dapat terjadi pada pasien pasca stroke dan saling berhubungan serta belum adanya penelitian mengenai gambaran gangguan

Alya Ramadhini 
tidur pada pasien stroke iskemik di Padang, penulis ingin meneliti hal ini.

\section{Metode}

Jenis penelitian ini adalah analitik observasional dengan desain cross sectional untuk mengetahui gambaran gangguan tidur yang terjadi pada pasien stroke iskemik serta melihat hubungan antara faktor risiko yang dimiliki oleh pasien dengan jenis gangguan tidur yang ditemukan. Penelitian dilakukan dari bulan Agustus 2019 - Februari 2020 di Poliklinik Neurologi Rumah Sakit Islam Ibnu Sina Padang, Sumatera Barat.

Populasi penelitian ini adalah pasien pasca stroke iskemik tahun 2019 di Rumah Sakit Ibnu Sina Padang. Sampel penelitian yang dipilih adalah pasien pasca stroke iskemik Rumah Sakit Islam Ibnu Sina Padang yang memenuhi kriteria inklusi dan tidak memiliki kriteria eksklusi. Kriteria inklusi subjek adalah pasien stroke iskemik $\geq 7$ hari pasca serangan stroke, kontrol berobat ke Poliklinik Neurologi RSI Ibnu Sina, pasien bersedia menjadi responden. Kriteria eksklusi subjek adalah pasien stroke yang sebelumnya memiliki riwayat gangguan tidur sebelum serangan stroke atau mengonsumsi obat-obatan yang memengaruhi status tidur (benzodiazepin agonis, GABA agonis, antiepilepsi, serotonin antagonis, GABA receptor inhibitor), pasien dengan penurunan kesadaran, pasien dengan gangguan kognitif (alzheimer atau demensia), Pasien dengan gangguan komunikasi, terdapat riwayat gangguan mental yaitu depresi dan psikosis, dan buta huruf

Data diperoleh dengan cara pengisian kuesioner oleh responden melalui metode wawancara terpimpin. Kuesioner yang digunakan adalah kuesioner modifikasi Specialised Centres of Research Sleep Questionnaire tahun 2005 untuk menentukan jenis gangguan tidur yang terdapat pada pasien, serta kuesioner demografi untuk melihat faktor risiko stroke yang dimiliki responden.

Data dianalisis secara statistik menggunakan program statistik berdasarkan variabel yang dinilai yaitu analisis univariat dan bivariat. Analisis univariat dilakukan untuk melihat distribusi frekuensi dari masing-masing variabel independen dan variabel dependen. Analisis bivariat dilakukan untuk menganalisis hubungan antara variabel independen dan variabel dependen. Hubungan dua variabel tersebut dianalisis dengan menggunakan Fisher's Exact Test dan dikatakan bermakna bila $\mathrm{p}<0,05$. Penelitian ini telah lulus kaji etik dengan nomor surat: 074/KEP/FK/2020.

\section{Hasil}

\section{Karakteristik Responden}

Penelitian ini dilakukan terhadap 57 responden yang memenuhi kriteria inklusi. Data demografis dan faktor risiko stroke responden ditunjukkan di tabel 1. Sebanyak 29 responden berusia lebih dari 65 tahun dengan rata-rata usia responden adalah $62,33 \pm 10,056$, dan sebanyak 31 responden berjenis kelamin laki-laki, dan 28 responden memiliki riwayat keluarga. Terdapat 56 responden memiliki hipertensi, 17 respon memiliki diabetes melitus, 26 responden memiliki dislipidemia, 7 responden memiliki penyakit jantung, 2 responden memiliki obesitas, 2 responden merokok, dan 2 responden memiliki riwayat mengonsumsi alkohol.

\section{Gambaran Gangguan Tidur pada Pasien Pasca Stroke Iskemik}

Sebanyak $37(64,9 \%)$ responden memiliki gangguan tidur. Dari jumlah responden yang memiliki gangguan tidur tersebut, terdapat 14 responden memiliki satu jenis gangguan tidur, 14 responden memiliki dua jenis gangguan tidur, 6 responden memiliki tiga jenis gangguan tidur, dan 3 responden memiliki 4 jenis gangguan tidur (tidak ditampilkan).

Berdasarkan jenis gangguan tidur yang diteliti, sebanyak $20 \quad(35,1 \%)$ responden menderita insomnia, $22 \quad(38,6 \%)$ responden menderita apneu tidur, $9(15,8 \%)$ menderita narkolepsi, dan $21(36,8 \%)$ responden menderita restless legs syndrome (tabel 2).

\section{Hubungan antara Faktor Risiko Stroke dengan Gangguan Tidur}

Menurut hasil penelitian ini, didapatkan terdapat hubungan antara umur dengan kejadian insomnia, yang mana didapatkan $p$ value 0,034 . Sedangkan untuk faktor risiko lainnya, tidak terdapat hubungan antara jenis kelamin $(p=0,532)$, diabetes mellitus $(p=0,558)$, dislipidemia $\quad(p=0,945)$, penyakit jantung 
$(\mathrm{p}=0,226)$, obesitas $(\mathrm{p}=1,000)$, dan merokok $(\mathrm{p}=1,000)$ dengan kejadian insomnia (tabel 3$)$.

Tabel 1. Data Demografi Responden

\begin{tabular}{|c|c|c|c|c|}
\hline Karakteristik & $\mathrm{f}$ & $\%$ & Mean & Std \\
\hline Usia & & & 62,33 & 10,056 \\
\hline$<65$ tahun & 28 & 49,1 & & \\
\hline$\geq 65$ tahun & 29 & 50,9 & & \\
\hline Total & 57 & 100 & & \\
\hline \multicolumn{5}{|l|}{ Jenis Kelamin } \\
\hline Laki-laki & 31 & 54,4 & & \\
\hline Perempuan & 26 & 45,6 & & \\
\hline Total & 57 & 100 & & \\
\hline \multicolumn{5}{|l|}{ Riwayat Keluarga } \\
\hline Ada & 28 & 49,1 & & \\
\hline Tidak & 29 & 50,9 & & \\
\hline Total & 57 & 100 & & \\
\hline \multicolumn{5}{|l|}{ Hipertensi } \\
\hline $\mathrm{Ya}$ & 56 & 98,2 & & \\
\hline Tidak & 1 & 1,8 & & \\
\hline Total & 57 & 100 & & \\
\hline \multicolumn{5}{|l|}{ Diabetes Melitus } \\
\hline $\mathrm{Ya}$ & 17 & 29,8 & & \\
\hline Tidak & 40 & 70,2 & & \\
\hline Total & 57 & 100 & & \\
\hline \multicolumn{5}{|l|}{ Dislipidemia } \\
\hline Ya & 26 & 45,6 & & \\
\hline Tidak & 31 & 54,4 & & \\
\hline Total & 57 & 100 & & \\
\hline \multicolumn{5}{|l|}{ Penyakit Jantung } \\
\hline Ya & 7 & 12,3 & & \\
\hline Tidak & 50 & 87,7 & & \\
\hline Total & 57 & 100 & & \\
\hline \multicolumn{5}{|l|}{ Obesitas } \\
\hline Ya & 2 & 3,5 & & \\
\hline Tidak & 55 & 96,5 & & \\
\hline Total & 57 & 100 & & \\
\hline \multicolumn{5}{|l|}{ Merokok } \\
\hline Ya & 2 & 3,5 & & \\
\hline Tidak & 55 & 96,5 & & \\
\hline Total & 57 & 100 & & \\
\hline \multicolumn{5}{|l|}{ Konsumsi Alkohol } \\
\hline $\mathrm{Ya}$ & 2 & 3,5 & & \\
\hline Tidak & 55 & 96,5 & & \\
\hline Total & 57 & 100 & & \\
\hline
\end{tabular}

Tabel 2. Jenis Gangguan Tidur pada Pasien Pasca Stroke Iskemik

\begin{tabular}{lcc}
\hline Gangguan Tidur & $\mathrm{f}$ & $\%$ \\
\hline Insomnia & 20 & 35,1 \\
Apneu tidur & 22 & 38,6 \\
Narkolepsi & 9 & 15,8 \\
RLS & 21 & 36,8 \\
\hline
\end{tabular}

Menurut hasil penelitian ini, tidak terdapat hubungan antara umur $(p=0,916)$, jenis kelamin $(p=0,985)$, diabetes melitus $(p=0,147)$, dislipidemia $\quad(p=0,105)$, penyakit jantung $(p=0,411)$, obesitas $(p=1,000)$, dan konsumsi alkohol $(p=1,000)$ dengan kejadian apneu (tabel 3).Hasil penelitian ini menunjukkan tidak terdapat hubungan antara umur $(\mathrm{p}=0,144)$, jenis kelamin $(\mathrm{p}=1,000)$, diabetes melitus $(\mathrm{p}=0,710)$, dan dislipidemia $\quad(\mathrm{p}=1,000)$ dengan kejadian narkolepsi (tabel 3).

Hasil penelitian ini menunjukkan tidak terdapat hubungan antara umur $(p=0,470)$, jenis kelamin $(\mathrm{p}=0,384)$, diabetes melitus $(\mathrm{p}=0,658)$, dislipidemia $\quad(p=0,182)$, penyakit jantung $(\mathrm{p}=0,404)$, dan obesitas $(\mathrm{p}=1,000)$ dengan kejadian RLS (tabel 3).

\section{Pembahasan}

Berdasarkan penelitian yang dilakukan pada pasien pasca stroke iskemik yang berobat di Rumah Sakit Ibnu Sina Padang didapatkan hasil penelitian sebanyak 37 responden memiliki gangguan tidur. Terdapat 14 responden $(24,6 \%)$ memiliki satu gangguan tidur, 14 responden $(24,6 \%)$ memiliki dua gangguan tidur, 6 responden $(10,5 \%)$ memiliki tiga jenis gangguan tidur, dan 3 responden $(3,5 \%)$ memiliki empat jenis gangguan tidur.

Terdapat 23 responden yang memiliki lebih dari satu jenis gangguan tidur dapat dikaitkan dengan gejala masing-masing gangguan tidur ini memengaruhi gangguan tidur lainnya. Zhang et. al. menganalisis keterkaitan insomnia dan obstructive sleep apnea (OSA) dengan mengevaluasi keluhan pasien OSA. Berdasarkan hasil analisisnya, didapatkan bahwa terdapat gejala insomnia yang terjadi pada pasien OSA tersebut seperti sulit tertidur, sulit mempertahankan tidur, dan terbangun terlalu dini. ${ }^{17}$ Penelitian yang dilakukan oleh Hein et. al menunjukkan bahwa excessive daytime sleepiness merupakan salah satu faktor risiko OSA pada pasien insomnia karena adanya fragmentasi tidur pada penderita insomnia yang mengalami OSA sehingga kualitas tidur menjadi menurun dan menyebabkan rasa mengantuk di siang hari. ${ }^{18}$ Excessive daytime sleepiness (EDS) juga lebih banyak terjadi pada pasien restless legs syndrome (RLS). ${ }^{19}$ 
Tabel 3. Hubungan antara Faktor Risiko Stroke dengan Jenis Gangguan Tidur

\begin{tabular}{|c|c|c|c|c|c|c|c|c|c|c|c|c|}
\hline \multirow{2}{*}{ Karakteristik } & \multicolumn{3}{|c|}{ Insomnia } & \multicolumn{3}{|c|}{ Apneu } & \multicolumn{3}{|c|}{ Narkolepsi } & \multicolumn{3}{|c|}{ RLS } \\
\hline & $\mathrm{Ya}$ & Tidak & $\mathrm{p}$ & $\mathrm{Ya}$ & Tidak & $\mathrm{p}$ & Ya & Tidak & $\mathrm{p}$ & $\mathrm{Ya}$ & Tidak & $\mathrm{p}$ \\
\hline Umur & & & 0,034 & & & 0,916 & & & 0,144 & & & 0,470 \\
\hline$<65$ tahun & 6 & 22 & & 11 & 17 & & 2 & 26 & & 9 & 19 & \\
\hline$>65$ tahun & 14 & 15 & & 11 & 18 & & 7 & 22 & & 12 & 17 & \\
\hline Jenis Kelamin & & & 0,532 & & & 0,985 & & & 1,000 & & & 0,384 \\
\hline Laki-laki & 12 & 19 & & 12 & 19 & & 5 & 26 & & 13 & 18 & \\
\hline Perempuan & 8 & 18 & & 10 & 16 & & 4 & 22 & & 8 & 18 & \\
\hline Hipertensi & & & - & & & - & & & - & & & - \\
\hline Ya & 19 & 37 & & 21 & 35 & & 8 & 48 & & 20 & 36 & \\
\hline Tidak & 1 & 0 & & 1 & 0 & & 1 & 0 & & 1 & 0 & \\
\hline DM & & & 0,558 & & & 0,147 & & & 0,710 & & & 0,658 \\
\hline Ya & 5 & 12 & & 9 & 8 & & 2 & 15 & & 7 & 26 & \\
\hline Tidak & 15 & 25 & & 13 & 27 & & 7 & 33 & & 14 & 10 & \\
\hline Dislipidemia & & & 0,945 & & & 0,105 & & & 1,000 & & & 0,182 \\
\hline Ya & 9 & 17 & & 13 & 13 & & 4 & 22 & & 12 & 14 & \\
\hline Tidak & 11 & 20 & & 9 & 22 & & 5 & 26 & & 9 & 22 & \\
\hline Peny. Jantung & & & 0,226 & & & 0,411 & & & - & & & 0,404 \\
\hline Ya & 4 & 3 & & 4 & 3 & & 0 & 7 & & 4 & 3 & \\
\hline Tidak & 16 & 34 & & 18 & 32 & & 9 & 41 & & 17 & 33 & \\
\hline Obesitas & & & 1,000 & & & 1,000 & & & - & & & 1,000 \\
\hline $\mathrm{Ya}$ & 1 & 1 & & 1 & 1 & & 0 & 2 & & 1 & 1 & \\
\hline Tidak & 19 & 36 & & 21 & 34 & & 9 & 46 & & 20 & 35 & \\
\hline Merokok & & & 1,000 & & & - & & & - & & & - \\
\hline $\mathrm{Ya}$ & 1 & 1 & & 2 & 0 & & 0 & 2 & & 2 & 0 & \\
\hline Tidak & 19 & 36 & & 20 & 35 & & 9 & 46 & & 19 & 36 & \\
\hline Alkohol & & & - & & & 1,000 & & & - & & & - \\
\hline Ya & 2 & 0 & & 1 & 1 & & 0 & 2 & & 2 & 0 & \\
\hline Tidak & 18 & 37 & & 21 & 34 & & 9 & 46 & & 19 & 36 & \\
\hline
\end{tabular}

Sebanyak 35,1\% responden mengalami insomnia. Angka kejadian insomnia pada pasien stroke ini hampir serupa dengan penelitian yang dilakukan oleh Yang-Kun et al., menyatakan bahwa prevalensi insomnia pada pasien stroke adalah sebesar $36,6 \%{ }^{20}$ Pada hasil penelitian ini tidak terdapat hubungan antara jenis kelamin, diabetes melitus, dislipidemia, penyakit jantung, obesitas, dan merokok dengan kejadian insomnia. Insomnia dapat disebabkan oleh beberapa etiologi baik dari aspek medis seperti lesi pada bagian otak yang mengatur fungsi tidur maupun secara psikologis seperti depresi serta gangguan kecemasan. ${ }^{21}$ Pada pasien stroke iskemik, berbagai etiologi ini dapat terjadi karena lesi di sel otak yang terjadi akibat stroke iskemik, adanya nyeri yang terjadi di ekstremitas pasca serangan stroke, serta rasa depresi yang muncul pada pasien stroke akibat berkurangnya kemampuan pasien tersebut untuk beraktivitas secara normal, dan memiliki kecemasan akan berbagai hal dalam dirinya karena stroke. Berbagai etiologi yang dimiliki oleh pasien stroke berkontribusi dalam menyebabkan insomnia. Namun, berdasarkan analisis hubungan antara faktor risiko stroke dengan kejadian insomnia, didapatkan bahwa terdapat hubungan antara usia dengan kejadian insomnia. Hasil penelitian ini hampir sama dengan penelitian yang dilakukan oleh Jaussent et. al. menunjukkan bahwa umur berhubungan dengan gejala insomnia yaitu sulit untuk mempertahankan tidurnya. Pada usia lebih tua, penuaan dapat mempengaruhi terjadi perubahan fragmentasi tidur yang disebabkan oleh adanya perubahan hormonal, perubahan homeostasis tubuh, kurangnya aktivitas fisik, kurangnya paparan cahaya matahari, dan apneu tidur yang menyebabkan terjadinya insomnia pada orang tua. ${ }^{22}$

Apneu tidur terjadi pada 38,6\% responden. Angka kejadian apneu tidur pada pada penelitian yang dilakukan oleh Keun et al. menunjukkan angka $20,3 \%$ pasien stroke iskemik mengalami obstructive sleep apnea (OSA). ${ }^{23}$ Angka 
kejadian OSA tinggi pada pasien stroke iskemik dapat berhubungan dengan faktor risiko hipertensi, diabetes melitus dan dislipidemia. Beberapa penelitian menunjukkan bahwa hipertensi berhubungan dengan OSA. Penelitian yang dilakukan oleh Hou et.al menyatakan bahwa terdapat hubungan yang signifikan antara hipertensi dengan kejadian OSA. ${ }^{24}$ Selain itu, penelitian yang dilakukan oleh Boyko et.al menunjukkan bahwa terdapat hubungan antara kejadian apneu tidur dengan diabetes. ${ }^{25}$ Penelitian lainnya yang dilakukan oleh Qian et al. menunjukkan bahwa dislipidemia berhubungan dengan OSA. ${ }^{26}$ Namun penelitian ini menunjukkan bahwa tidak terdapat hubungan antara usia jenis kelamin, diabetes melitus, dislipidemia, penyakit jantung, obesitas, dan konsumsi alkohol pada pasien stroke dengan kejadian apneu. Hal ini dapat dikaitkan karena OSA pada pasien stroke sendiri dapat memengaruhi patofisiologi stroke melalui mekanisme hipoksia yang menyebabkan adanya stres oksidatif, peningkatan aktivitas saraf simpatis dan inflamasi yang berkontribusi kepada aterosklerosis dan hipertensi, serta penyakit diabetes melitus dan dislipidemia yang berkontribusi menjadi faktor risiko stroke.

Narkolepsi juga ditemukan pada 15,8\% responden yang mengikuti penelitian ini. Penelitian yang dilakukan oleh Suh et al. menyebutkan bahwa kejadian narkolepsi pada pasien stroke iskemik sebesar 14,4\%.27 Berdasarkan analisis hubungan antara faktor risiko stroke dengan kejadian narkolepsi, didapatkan bahwa tidak terdapat hubungan antara usia jenis kelamin, diabetes melitus, dan dislipidemia dengan kejadian narkolepsi. Beberapa penyebab terjadinya narkolepsi pada pasien stroke adalah gangguan tidur lain yang menyertai pasien stroke iskemik seperti insomnia dan apneu tidur di malam hari, dan nyeri pada kaki pasca terjadinya stroke karena gangguan saraf pada otak. Penelitian oleh Suh et al. juga menyebutkan bahwa terdapat hubungan antara buruknya kualitas tidur di malam hari dan rasa nyeri berhubungan dengan kejadian narkolepsi atau excessive daytime sleepiness. ${ }^{27}$

Sedangkan untuk restless legs syndrome (RLS), hasil penelitian ini menunjukkan terdapat $36,8 \%$ yang mengalami gangguan tidur ini. Penelitian ini memiliki hasil yang lebih besar dibandingkan dengan penelitian yang dilakukan oleh Seung-Jae et al. yang menyebutkan terdapat $12,4 \%$ pasien stroke yang mengalami RLS. ${ }^{13}$ Berdasarkan analisis hubungan antara faktor risiko stroke dengan kejadian restless legs syndrome (RLS), didapatkan bahwa tidak terdapat hubungan antara usia jenis kelamin, diabetes melitus, dislipidemia, penyakit jantung dan obesitas dengan kejadian RLS. Restless legs syndrome disebabkan oleh adanya kerusakan anatomis pada daerah otak terutama ganglia basalis-batang otak. Selain itu adanya perubahan neurotransmiter di daerah otak seperti dopamin merupakan salah satu patofisiologi terjadinya RLS, yang mana pada pasien stroke terjadi gangguan pada perilisan dopamin di otak. ${ }^{28}$

\section{Simpulan}

Berdasarkan hasil penelitian, Kejadian stroke iskemik lebih banyak ditemukan pada kelompok usia $\geq 65$ tahun, laki-laki, dan pasien yang memiliki hipertensi. Selain itu, didapatkan gangguan tidur yang paling banyak ditemukan pada responden adalah apneu tidur.

Kesimpulan hasil analisis penelitian ini adalah Terdapat hubungan antara usia dengan kejadian insomnia namun tidak terdapat hubungan antara faktor risiko lainnya (jenis kelamin, diabetes melitus, dislipidemia, obesitas, merokok, dan konsumsi alkohol) dengan jenis gangguan tidur (insomnia, apneu, narkolepsi, restless legs syndrome).

\section{Ucapan Terima Kasih}

Ucapan terimakasih diberikan kepada pihak Rumah Sakit Ibnu Sina Padang yang memberikan izin untuk melakukan penelitian di Poliklinik Neurologi Rumah Sakit Ibnu Sina Padang serta responden yang bersedia mengikuti penelitian ini.

\section{Daftar Pustaka}

1. Avan A, Digaleh H, Napoli M D, Stranges S, Behrouz R, Shojaeianbabaei G, et al. Socioeconomic status and stroke incidence, prevalence, mortality, and worldwide burden: An ecological analysis from the Global Burden of Disease Study 2017. BMC Med. 2019;17(191):1-30.

2. Johnson CO, Nguyen M, Roth GA, Nichols E, Alam T, Abate D, et al. Global, regional, and national burden of stroke, 1990-2016: a systematic analysis for the Global Burden of Disease Study 2016. Lancet Neurol. 2019;18(5):439-58.

3. Kemenkes. RISKESDAS 2018. 2018. Departemen Kesehatan

RI. 
http://www.depkes.go.id/resources/download/infoterkini/materi_rakorpop_2018/Hasil Riskesdas 2018.pdf - diakses September 2019

4. Kemenkes. Info Datin - Situasi Kesehatan Jantung. Pusat Data dan Informasi Kementrian Kesehatan RI. 2014.

5. Boehme AK, Esenwa C, Elkind MSV. Stroke risk factors, genetics, and prevention. Circ Res. 2018;120(3):47295.

6. Katan M, Luft A. Global Burden of Stroke. Semin Neurol. 2018;38:208-11.

7. Pasic Z, Smajlovic D, Dostovic Z, Kojic B, Selmanovic S. Incidence and types of sleep disorders in patients with stroke. Med Arh. 2011:65(4):225-8.

8. Aslanyan S, Weir CJ, Johnston SC, Lees KR. Poststroke neurological improvement within 7 days is associated with subsequent deterioration. Stroke. 2004;35(9):2165-70.

9. Duss SB, Seiler A, Markus H, Pace M, Adamantidis A, Müri $M$, et al. The role of sleep in recovery following ischemic stroke: a review of human and animal data. Neurobiology of Sleep and Circadian Rhythms,2016;11(3):1-41.

10. Leppävuori A, Pohjasvaara $T$, Vataja R, Kaste $M$, Erkinjuntti T. Insomnia in ischemic stroke patients. Cerebrovasc Dis. 2002;14(2):90-7.

11. Johnson KG, Johnson DC. Frequency of sleep apnea in stroke and TIA patients: A meta-analysis. J Clin Sleep Med. 2010;6(2):131-7.

12. Sterr A, Herron K, Dijk DJ, Ellis J. Time to wake-up: Sleep problems and daytime sleepiness in long-term stroke survivors. Brain Inj. 2008;22 (7-8):575-9.

13. Lee SJ, Kim JS, Song IU, An JY, Kim YI, Lee KS. Poststroke restless legs syndrome and lesion location: Anatomical considerations. Mov Disord. 2009;24(1):77-84.

14. Siccoli MM, Valko PO, Hermann DM, Bassetti CL. Central periodic breathing during sleep in 74 patients with acute ischemic stroke - Neurogenic and cardiogenic factors. J Neurol. 2008;255(11):1687-92.

15. Khot SP, Morgenstern LB. Sleep and Stroke. Stroke. 2019;50:1612-7.

16. Wallace DM, Ramos AR, Rundek T. Sleep disorders and stroke. Int J Stroke. 2013;7(3):231-42.

17. Zhang Y, Ren R, Lei F, Zhou J, Zhang J, Wing YK, et al. Worldwide and regional prevalence rates of cooccurrence of insomnia and insomnia symptoms with obstructive sleep apnea: A systematic review and meta-analysis. Sleep Med Rev. 2019;45:1-17.

18. Hein M, Lanquart JP, Loas G, Hubain P, Linkowski P. Prevalence and risk factors of moderate to severe obstructive sleep apnea syndrome in insomnia sufferers: A study on 1311 subjects. Respir Res. 2017;18(1):1-10.

19. Šiarnik P, Klobučníková K, Šurda P, Putala M, Šutovský S, Kollár B, et al. Excessive daytime sleepiness in acute ischemic stroke: Association with restless legs syndrome, diabetes mellitus, obesity, and sleepdisordered breathing. J Clin Sleep Med. 2018;14(1):95100.

20. Chen YK, Lu JY, Mok VCT, Ungvari GS, Chu WCW, Wong $\mathrm{KS}$, et al. Clinical and radiologic correlates of insomnia symptoms in ischemic stroke patients. Int J Geriatr Psychiatry. 2011;26(5):451-7.

21. Singh P. Insomnia : A sleep disorder : Its causes, symptoms and treatments. Int J Med Health Res 2016;2(10):37-41.

22. Jaussent I, Dauvilliers Y, Ancelin ML, Dartigues JF,
Tavernier B, Touchon J, et al. Insomnia symptoms in older adults: Associated factors and gender differences. Am J Geriatr Psychiatry. 2011;19(1):88-97.

23. Kim KT, Moon HJ, Yang JG, Sohn SII, Hong JH, Cho YW. The prevalence and clinical significance of sleep disorders in acute ischemic stroke patients-a questionnaire study. Sleep Breath. 2017;21(3):759-65.

24. Hou H, Zhao Y, Yu W, Dong H, Xue X, Ding J, et al. Association of obstructive sleep apnea with hypertension: A systematic review and meta-analysis. J Glob Health. 2018;8(1):1-10.

25. Boyko EJ, Seelig AD, Jacobson IG, Hooper TI, Smith B, Smith TC, et al. Sleep characteristics, mental health, and diabetes risk: A prospective study of U.S. Military service members in the millennium cohort study. Diabetes Care. 2013;36(10):3154-61.

26. Qian Y, Yi H, Zou J, Meng L, Tang X, Zhu H, et al. Independent Association between Sleep Fragmentation and Dyslipidemia in Patients with Obstructive Sleep Apnea. Sci Rep. 2016;6(May):1-8.

27. Suh M, Choi-Kwon S, Kim JS. Sleep Disturbances at 3 Months after Cerebral Infarction. Eur Neurol. 2016;75:75-81.

28. Woo HG, Lee D, Hwang KJ, Ahn TB. Post-stroke restless leg syndrome and periodic limb movements in sleep. Acta Neurol Scand. 2017;135(2):204-10. 